\title{
23
}

\section{Sources of Pollutants in Urban Areas (Part 1) - Older Monitoring Projects}

\author{
Robert Pitt, Roger Bannerman, Shirley Clark and Derek Williamson
}

Information concerning source area runoff characteristics during wet weather events can be very important when developing stormwater management plans that incorporate source area controls, or changes in development patterns. This information is also important when calibrating or testing many stormwater models. Unfortunately, this information is not readily available and can be expensive and tedious to collect. However, a substantial amount of these data have been collected over the past several decades, but are not well known. This chapter, and the next, present summaries of these data, specifically source area sheetflow and particulate quality for a variety of areas. Information is presented for many source areas, including urban wet and dry atmospheric deposition, roofs, urban soils, streets and other pavements. Information showing concentrations of conventional pollutants, heavy metals, and selected organic compounds is summarized for major land use categories. The following chapter summarizes additional source area sheetflow information obtained during detailed projects in Alabama and Wisconsin during the 1990s, and summarizes newer data collected elsewhere.

Much of the information was collected in the 1970s and 1980s as part of stormwater research projects for the EPA. This chapter summarizes source area sheetflow quality data obtained from a number of studies conducted in California, Washington, Nevada, Illinois, Ontario, Colorado, New Hampshire, and New York during 1970s and 1980s. Most of the early data obtained were for street dirt chemical quality as part of street cleaning research projects, but a relatively large amount of parking area runoff and roof runoff quality data

Pitt, R.E., R. Bannerman, S. Clark and D. Williamson. 2005. "Sources of Pollutants in Urban Areas (Part 1) - Older Monitoring Projects." Journal of Water Management Modeling R223-23. doi: 10.14796/JWMM.R223-23.

(C) CHI 2005 www.chijournal.org ISSN: 2292-6062 (Formerly in Effective Modeling of Urban Water Systems. ISBN: 0-9736716-0-2) 
was also obtained during these early projects. However, only a few of these studies evaluated a broad range of source areas or land uses.

\subsection{Source Area Pollutant Generation Processes}

The following discussion stresses stormwater pollutants originating from automobile activities and atmospheric deposition. More limited information is available for other source areas, such as roof runoff and runoff from landscaped areas.

\subsubsection{Automotive Activities}

Most of the street surface dust and dirt materials (by weight) are local soil erosion products, while some materials are contributed by motor vehicle emissions and wear (Shaheen 1975). Minor contributions are made by erosion of street surfaces in good condition. The specific makeup of street surface contaminants is a function of many conditions and varies widely (Pitt 1979).

Pitt (1979) found that automobile tire wear is a major source of zinc in urban runoff and is mostly deposited on street surfaces and nearby adjacent areas. Other important sources of zinc are galvanized metals. About half of the airborne particulates lost due to tire wear settle out on the street and the majority of the remaining particulates settle within about six meters of the roadway. Exhaust particulates, fluid losses, drips, spills and mechanical wear products can all contribute lead to street dirt. Many heavy metals are important pollutants associated with automobile activity. Most of these automobile pollutants affect parking lots and street surfaces. However, some of the automobile related materials also affect areas adjacent to the streets. This occurs through the wind transport mechanism after being resuspended from the road surface by traffic-induced turbulence.

Automobile exhaust particulates contribute many important heavy metals to street surface particulates and to urban runoff and receiving waters. The most notable of these heavy metals has been lead. However, since the late 1980 s, the concentrations of lead in stormwater has decreased substantially (by about ten times) compared to early 1970 observations. This decrease, of course, is associated with significantly decreased consumption of leaded gasoline.

Solomon and Natusch (1977) studied automobile exhaust particulates in conjunction with a comprehensive study of lead in the Champaign-Urbana, IL area. They found that the exhaust particulates existed in two distinct 
morphological forms. The smallest particulates were almost perfectly spherical, having diameters in the range of 0.1 to $0.5 \mu \mathrm{m}$. These small particles consisted almost entirely of $\mathrm{Pb}, \mathrm{Br}, \mathrm{Cl}$ (lead, bromine, chlorine) at the time of emission. Because the particles are small, they are expected to remain airborne for considerable distances and can be captured in the lungs when inhaled. The researchers concluded that the small particles are formed by condensation of $\mathrm{PbBrCl}$ vapor onto small nucleating centers, which are probably introduced into the engine with the filtered engine air.

Solomon and Natusch (1977) found that the second major form of automobile exhaust particulates were rather large, being roughly 10 to $20 \mu \mathrm{m}$ in diameter. These particles typically had irregular shapes and somewhat smooth surfaces. The elemental compositions of these irregular particles were found to be quite variable, being predominantly iron, calcium, lead, chlorine and bromine. They found that individual particles did contain aluminum, zinc, sulfur, phosphorus and some carbon, chromium, potassium, sodium, nickel and thallium. Many of these elements (bromine, carbon, chlorine, chromium, potassium, sodium, nickel, phosphorus, lead, sulfur, and thallium) are most likely condensed, or adsorbed, onto the surfaces of these larger particles during passage through the exhaust system. They believed that these large particles originate in the engine or exhaust system because of their very high iron content. They found that $50 \%$ to $70 \%$ of the emitted lead was associated with these large particles, which would be deposited within a few meters of the emission point onto the roadway, because of their aerodynamic properties.

Solomon and Natusch (1977) also examined urban particulates near roadways and homes in urban areas. They found that lead concentrations in soils were higher near roads and houses. This indicated the capability of road dust and peeling house paint to contaminate nearby soils. The lead content of the soils ranged from 130 to about $1,200 \mathrm{mg} / \mathrm{kg}$. Koeppe (1977), during another element of the Champaign-Urbana lead study, found that lead was tightly bound to various soil components. However, the lead did not remain in one location, but it was transported both downward in the soil profile and to adjacent areas through both natural and man-assisted processes.

\subsubsection{Atmospheric Deposition}

Wind transported materials are commonly called "dustfall." Dustfall includes sedimentation, coagulation with subsequent sedimentation and impaction. Dustfall is normally measured by collecting dry samples, excluding rainfall and snowfall. If rainout and washout are included, one has a measure of total 
atmospheric fallout. This total atmospheric fallout is sometimes called "bulk precipitation." Rainout removes contaminants from the atmosphere by condensation processes in clouds, while washout is the removal of contaminants by the falling rain. Therefore, precipitation can include natural contamination associated with condensation nuclei in addition to collecting atmospheric pollutants as the rain or snow falls. In some areas, the contaminant contribution by dry deposition is small, compared to the contribution by precipitation (Malmquist 1978). However, in heavily urbanized areas, dustfall can contribute more of an annual load than the wet precipitation, especially when dustfall includes resuspended materials.

Atmospheric processes affecting urban runoff pollutants include dry dustfall and precipitation quality. These have been monitored in many urban and rural areas. In many instances, however, the samples were combined as a bulk precipitation sample before processing. Automatic precipitation sampling equipment can distinguish between dry periods of fallout and precipitation. These devices cover and uncover appropriate collection jars exposed to the atmosphere. Much of this information has been collected as part of the Nationwide Urban Runoff Program (NURP) and the Atmospheric Deposition Program, both sponsored by the USEPA (EPA 1983).

Urban atmospheric deposition information must be interpreted carefully, because of the ability of many polluted dust and dirt particles to be resuspended and then redeposited within the urban area. In many cases, the atmospheric deposition measurements include material that was previously residing and measured in other urban runoff pollutant source areas. Also, only small amounts of the atmospheric deposition material would directly contribute to runoff. Rain is subjected to infiltration and the dry fall particulates are likely mostly incorporated with surface soils and only small fractions are then eroded during rains. Therefore, mass balances and determinations of urban runoff deposition and accumulation from different source areas can be highly misleading, unless transfer of material between source areas and the effective yield of this material to the receiving water is considered. Depending on the land use, relatively little of the dustfall in urban areas likely contributes to stormwater discharges.

Dustfall and precipitation affect all of the major urban runoff source areas in an urban area. Dustfall, however, is typically not a major pollutant source but fugitive dust is mostly a mechanism for pollutant transport. Most of the dustfall monitored in an urban area is resuspended particulate matter from street surfaces or wind erosion products from vacant areas (Pitt 1979). Point source pollutant emissions can also significantly contribute to dustfall 
pollution, especially in industrial areas. Transported dust from regional agricultural activities can also significantly affect urban stormwater.

Table 23.1 summarizes rain quality reported by several researchers. As expected, the non-urban area rain quality can be substantially better than urban rain quality. Many of the important heavy metals, however, have not been detected in rain in many areas of the country. The most important heavy metals found in rain have been lead and zinc, both being present in rain in concentrations from about $20 \mu \mathrm{g} / \mathrm{L}$ up to several hundred $\mu \mathrm{g} / \mathrm{L}$. It is expected that more recent lead rainfall concentrations would be substantially less, reflecting the decreased use of leaded gasoline since these measurements were taken. Iron is also present in relatively high concentrations in rain (about 30 to $40 \mu \mathrm{g} / \mathrm{L})$.

The concentrations of various urban runoff pollutants associated with dry dustfall are summarized in Table 23.2. Urban, rural and oceanic dry dustfall samples contained more than $5,000 \mathrm{mg}$ iron $/ \mathrm{kg}$ total solids. Zinc and lead were present in high concentrations. These constituents can have concentrations of up to several thousand $\mathrm{mg}$ of pollutant per $\mathrm{kg}$ of dry dustfall. Spring, et al. (1978) monitored dry dustfall near a major freeway in Los Angeles, CA. Based on a series of samples collected over several months, they found that lead concentrations on and near the freeway can be about $3,000 \mathrm{mg} / \mathrm{kg}$, but as low as about $500 \mathrm{mg} / \mathrm{kg} 150 \mathrm{~m}$ (500 feet) away. In contrast, the chromium concentrations of the dustfall did not vary substantially between the two locations and approached oceanic dustfall chromium concentrations.

Much of the monitored atmospheric dustfall and precipitation would not reach the urban runoff receiving waters. The percentage of dry atmospheric deposition retained in a rural watershed was extensively monitored and modeled in Oakridge, TN (Barkdoll, et al. 1977). They found that about 98\% of the lead in dry atmospheric deposits was retained in the watershed, along with about $95 \%$ of the cadmium, $85 \%$ of the copper, $60 \%$ of the chromium and magnesium and $75 \%$ of the zinc and mercury. Therefore, if the dry deposition rates were added directly to the yields from other urban runoff pollutant sources, the resultant urban runoff loads would be very much overestimated.

Tables 23.3 and 23.4 report bulk precipitation (dry dustfall plus rainfall) quality and deposition rates as reported by several researchers. For the Knoxville, KY, area (Betson 1978), chemical oxygen demand (COD) was found to be the largest component in the bulk precipitation monitored, followed by filterable residue and nonfilterable residue. Table 23.4 also 
presents the total watershed bulk precipitation, as the percentage of the total stream flow output, for the three Knoxville watersheds studies. This shows that almost all of the pollutants presented in the urban runoff streamflow outputs could easily be accounted for by bulk precipitation deposition alone. Betson concluded that bulk precipitation is an important component for some of the constituents in urban runoff, but the transport and resuspension of particulates from other areas in the watershed are overriding factors.

Rubin (1976) stated that resuspended urban particulates are returned to the earth's surface and waters in four main ways: gravitational settling, impaction, precipitation and washout. Gravitational settling, as dry deposition, returns most of the particles.

Table 23.1 Summary of reported rain quality.

\begin{tabular}{|c|c|c|c|c|c|c|}
\hline & 1 & 2 & 3 & 4 & 5 & 6 \\
\hline Suspended solids, $\mathrm{mg} / \mathrm{L}$ & & & & 13 & & \\
\hline Volatile suspended solids, $\mathrm{mg} / \mathrm{L}$ & & & & 3.8 & & \\
\hline Inorganic nitrogen, $\mathrm{mg} / \mathrm{L}$ as $\mathrm{N}$ & & & & 0.69 & & \\
\hline Ammonia, $\mathrm{mg} / \mathrm{L}$ as $\mathrm{N}$ & & & & & 0.7 & \\
\hline Nitrates, $\mathrm{mg} / \mathrm{L}$ as $\mathrm{N}$ & & & & & 0.3 & \\
\hline Total phosphates, $\mathrm{mg} / \mathrm{L}$ as $\mathrm{P}$ & & & & & $<0.1$ & \\
\hline Ortho phosphate, $\mathrm{mg} / \mathrm{L}$ as $\mathrm{P}$ & & & & 0.24 & & \\
\hline Scandium, $\mu \mathrm{g} / \mathrm{L}$ & $<0.002$ & nd & & & & nd \\
\hline Titanium, $\mu \mathrm{g} / \mathrm{L}$ & nd & nd & & & & nd \\
\hline Vanadium, $\mu \mathrm{g} / \mathrm{L}$ & nd & nd & & & & nd \\
\hline Chromium, $\mu \mathrm{g} / \mathrm{L}$ & $<2$ & nd & 1 & & & nd \\
\hline Manganese, $\mu \mathrm{g} / \mathrm{L}$ & 2.6 & 3.4 & & & & 12 \\
\hline Iron, $\mu \mathrm{g} / \mathrm{L}$ & 32 & 35 & & & & \\
\hline Cobalt, $\mu \mathrm{g} / \mathrm{L}$ & 0.04 & nd & & & & nd \\
\hline Nickel, $\mu \mathrm{g} / \mathrm{L}$ & nd & nd & 3 & & & 43 \\
\hline Copper, $\mu \mathrm{g} / \mathrm{L}$ & 3.1 & 8.2 & 6 & & & 21 \\
\hline Zinc, $\mu \mathrm{g} / \mathrm{L}$ & 20 & 30 & 44 & & & 107 \\
\hline Lead, $\mu \mathrm{g} / \mathrm{L}$ & & & 45 & & & \\
\hline
\end{tabular}

Column 1. Rural-Northwest (Quilayute, WA) ${ }^{1} ; 2$. Rural-Northeast (Lake George, NY) ${ }^{1} ; 3$. Urban Northwest (Lodi, NJ) ${ }^{2}$; 4. Urban-Midwest (Cincinnati, OH) ${ }^{3}$; 5. Other Urban ${ }^{3}$; 6. Continental Avg. (32 locations) ${ }^{1}$

Notes: 1.Rubin 1976; 2. Wilbur and Hunter 1980; 3. Manning, et al. 1976.

Rubin (1976) stated that resuspended urban particulates are returned to the earth's surface and waters in four main ways: gravitational settling, impaction, precipitation and washout. Gravitational settling, as dry deposition, returns most of the particles. This not only involves the settling of relatively large fly ash and soil particles, but also the settling of smaller particles that 
collide and coagulate. Rubin stated that particles that are less than $0.1 \mu \mathrm{m}$ in diameter move randomly in the air and collide often with other particles.

These small particles can grow rapidly by this coagulation process. These small particles would soon be totally depleted in the air if they were not constantly replenished. Particles in the 0.1 to $1.0 \mu \mathrm{m}$ range are also removed primarily by coagulation. These larger particles grow more slowly than the smaller particles because they move less rapidly in the air, are somewhat less numerous and, therefore, collide less often with other particles. Particles with diameters larger than $1 \mu \mathrm{m}$ have appreciable settling velocities. Those particles about $10 \mu \mathrm{m}$ in diameter can settle rapidly, although they can be kept airborne for extended periods of time and for long distances by atmospheric turbulence.

Table 23.2 Atmosphere Dustfall Quality

\begin{tabular}{|c|c|c|c|c|c|}
\hline $\begin{array}{l}\text { Constituent, (mg } \\
\text { constituent } / \mathrm{kg} \text { total solids) }\end{array}$ & Urban $^{1}$ & $\begin{array}{l}\text { Rural/ } \\
\text { suburban }^{1}\end{array}$ & Oceanic $^{1}$ & $\begin{array}{l}\text { Near } \\
\text { freeway } \\
(\mathrm{LA})^{2}\end{array}$ & $\begin{array}{l}500^{\prime} \\
\text { from } \\
\text { freeway } \\
(\mathrm{LA})^{2}\end{array}$ \\
\hline $\mathrm{pH}$ & & & & 4.3 & 4.7 \\
\hline Phosphate-Phosphorous & & & & 1200 & 1600 \\
\hline Nitrate-Nitrogen, $\mu \mathrm{g} / \mathrm{L}$ & & & & 5800 & 9000 \\
\hline Scandium, $\mu \mathrm{g} / \mathrm{L}$ & 5 & 3 & 4 & & \\
\hline Titanium, $\mu \mathrm{g} / \mathrm{L}$ & 380 & 810 & 2700 & & \\
\hline Vanadium, $\mu \mathrm{g} / \mathrm{L}$ & 480 & 140 & 18 & & \\
\hline Chromium, $\mu \mathrm{g} / \mathrm{L}$ & 190 & 270 & 38 & 34 & 45 \\
\hline Manganese, $\mu \mathrm{g} / \mathrm{L}$ & 6700 & 1400 & 1800 & & \\
\hline Iron, $\mu \mathrm{g} / \mathrm{L}$ & 24000 & 5400 & 21000 & & \\
\hline Cobalt, $\mu \mathrm{g} / \mathrm{L}$ & 48 & 27 & 8 & & \\
\hline Nickel, $\mu \mathrm{g} / \mathrm{L}$ & 950 & 1400 & & & \\
\hline Copper, $\mu \mathrm{g} / \mathrm{L}$ & 1900 & 2700 & 4500 & & \\
\hline Zinc, $\mu \mathrm{g} / \mathrm{L}$ & 6700 & 1400 & 230 & & \\
\hline Lead, $\mu \mathrm{g} / \mathrm{L}$ & & & & 2800 & 550 \\
\hline
\end{tabular}

The second important particulate removal process from the atmosphere is impaction. Impaction of particles near the earth's surface can occur on vegetation, rocks and building surfaces. The third form of particulate removal from the atmosphere is precipitation, in the form of rain and snow. This is caused by the rainout process where the particulates are removed in the cloudforming process. The fourth important removal process is washout of the particulates below the clouds during the precipitation event. Therefore, it is easy to see that re-entrained particles (especially from street surfaces, other 
paved surfaces, rooftops and from soil erosion) in urban areas can be readily redeposited through these various processes, either close to the points of origin or at some distance away.

Pitt (1979) monitored airborne concentrations of particulates near typical urban roads. He found that on a number basis, the downwind roadside particulate concentrations were about $10 \%$ greater than upwind conditions. About $80 \%$ of the concentration increases, by number, were associated with particles in the 0.5 to $1.0 \mu \mathrm{m}$ size range. However, about $90 \%$ of the particle concentration increases by weight were associated with particles greater than $10 \mu \mathrm{m}$. Pitt found that the rate of particulate resuspension from street surfaces increases when the streets are dirty (cleaned infrequently) and varied widely for different street and traffic conditions.

The resuspension rates were calculated based upon observed long-term accumulation conditions on street surfaces for many different study area conditions, and varied from about 0.30 to $3.6 \mathrm{~kg}$ per curb-km (one to $12 \mathrm{lb}$ per curb-mile) of street per day.

Table 23.3 Bulk precipitation quality

\begin{tabular}{llll}
\hline \multicolumn{1}{c}{ Constituent (all } & $\begin{array}{l}\text { Urban (average of } \\
\text { Knoxville St. } \\
\text { Louis \& }\end{array}$ & $\begin{array}{l}\text { Rural } \\
\text { (Tennessee) } 1\end{array}$ & $\begin{array}{l}\text { Urban } \\
\text { (Guteburg, } \\
\text { Sweden) } 2\end{array}$ \\
& 3.4 & & \\
\hline Calcium & 0.6 & 0.4 & \\
Magnesium & 1.2 & 0.1 & \\
Sodium & 2.5 & 0.3 & \\
Chlorine & 8.0 & 0.2 & \\
Sulfate & 5.0 & 8.4 & \\
pH & 2.5 & 4.9 & 1 \\
Organic Nitrogen & 0.4 & 1.2 & 0.03 \\
Ammonia Nitrogen & 0.5 & 0.4 & \\
Nitrite plus Nitrate-N & 1.1 & 0.4 & \\
Total phosphate & 1.8 & 0.8 & \\
Potassium & 0.8 & 0.6 & 0.05 \\
Total iron & 0.03 & 0.7 & \\
Manganese & 0.03 & 0.05 & 10 \\
Lead & 0.01 & 0.01 & 0.08 \\
Mercury & 16 & 0.0002 & 0.02 \\
Nonfilterable residue & 65 & & \\
Chemical Oxygen Demand & & & \\
Zinc & & & \\
\hline Copper & & & \\
\hline
\end{tabular}

Notes: 1. Betson 1978; 2. Malmquist 1978.

Murphy (1975) described a Chicago study where airborne particulate material within the city was microscopically examined, along with street surface 
particulates. Particulates from both of these areas were found to be similar (mostly limestone and quartz) indicating that the airborne particulates were most likely resuspended street surface particulates, or from the same source.

PEDCo (1977) found that the re-entrained portion of the traffic-related particulate emissions (by weight) is an order of magnitude greater than the direct emissions accounted for by vehicle exhaust and tire wear. They also found that particulate resuspensions from a street are directly proportional to the traffic volume and that the suspended particulate concentrations near the streets are associated with relatively large particle sizes. The medium particle size found, by weight, was about $15 \mu \mathrm{m}$, with about $22 \%$ of the particulates occurring at sizes greater than $30 \mu \mathrm{m}$. These relatively large particle sizes resulted in substantial particulate fallout near the road. They found that about $15 \%$ of the resuspended particulates fall out at $10 \mathrm{~m}, 25 \%$ at $20 \mathrm{~m}$, and $35 \%$ at $30 \mathrm{~m}$ from the street (by weight).

In a similar study Cowherd, et al. (1977) reported a wind erosion threshold value of about $5.8 \mathrm{~m} / \mathrm{s}(13 \mathrm{mph})$. At this wind speed, or greater, significant dust and dirt losses from the road surface could result, even in the absence of traffic-induced turbulence.

Table 23.4 Urban bulk precipitation deposition rates (Betson 1978)1

\begin{tabular}{rlrr}
\hline Rank & \multicolumn{1}{c}{ Constituent } & $\begin{array}{c}\text { Average Bulk } \\
\text { Deposition Rate } \\
(\mathrm{kg} / \mathrm{ha} / \mathrm{yr})\end{array}$ & $\begin{array}{c}\text { Average Bulk Prec. as } \\
\text { a \% of Total } \\
\text { Streamflow Output }\end{array}$ \\
\hline 1 & Chemical oxygen demand & 530 & 490 \\
2 & Filterable residue & 310 & 60 \\
3 & Nonfilterable residue & 170 & 120 \\
4 & Alkalinity & 150 & 120 \\
5 & Sulfate & 96 & 470 \\
6 & Chloride & 47 & 360 \\
7 & Calcium & 38 & 170 \\
8 & Potassium & 21 & 310 \\
9 & Organic nitrogen & 17 & 490 \\
10 & Sodium & 15 & 270 \\
11 & Silica & 11 & 130 \\
12 & Magnesium & 9 & 180 \\
13 & Total Phosphate & 9 & 130 \\
14 & Nitrite and Nitrate-N & 5.7 & 360 \\
15 & Soluble phosphate & 5.3 & 170 \\
16 & Ammonia Nitrogen & 3.2 & 1,100 \\
17 & Total Iron & 1.9 & 47 \\
18 & Fluoride & 1.8 & 300 \\
19 & Lead & 1.1 & 650 \\
20 & Manganese & 0.54 & 270 \\
21 & Arsenic & 0.07 & 720 \\
\hline 22 & Mercury & 0.008 & 250 \\
\hline & & & KY Note: \\
\hline
\end{tabular}

Note: 1. Average for three Knoxville, KY, watersheds. 
Rolfe and Reinbold (1977) also found that most of the particulate lead from automobile emissions settled out within $100 \mathrm{~m}$ of roads. However, the automobile lead does widely disperse over a large area. They found, through multi-elemental analyses, that the settled outdoor dust collected at or near the curb was contaminated by automobile activity and originated from the streets.

\subsection{Particulate Quality}

A number of early stormwater studies collected dry soil samples from various urban surfaces for gravimetric, particle size, and quality analyses. Many of these data are summarized in this section. Burton and Pitt (2002) describe how these samples were obtained. In general, they were vacuumed from hard surfaces in very specific patterns in order to determine the accumulation rates. Related tests (such as conducted by Pitt, 1987, and summarized in Burton and Pitt, 2002) determined how much of this material would washoff during rains. The accumulation rates and washoff conditions are summarized in another chapter of this book.

The data summarized in this section focus on average concentration values for different pollutants, land uses, and source areas. Ranges or variations are not presented due to the vast amount of data obtained and how the samples were composited before chemical analyses. Generally, each sample comprised 12 to 40 subsamples for each collection. Collections were usually made several times a week for up to several years from 5 to 10 areas per project. Therefore, each project typically included data from hundreds to thousands of samples. Normally, each sample was separated into several particle sizes using standard sieves. Each sample fraction was retained, usually in zip lock bags. Seasonal composites were then made of all similar sized samples for each source area for the chemical analyses. The data shown in this section are averages of the chemical analyses for the smallest particle sizes for all samples representing each land use for each project.

Particulate potency factors (usually expressed as $\mathrm{mg}$ pollutant $/ \mathrm{kg}$ dry particulate residue) for many samples are summarized on Tables 23.5 and 23.6. These data can help recognize critical source areas, but care must be taken if they are used for predicting runoff quality because of likely differential effects due to washoff and erosion from the different source areas.

These data show the variations in chemical quality between particles from different land uses and source areas. Typically, the potency factors increase as 
the use of an area becomes more intensive, but the variations are slight for different locations throughout the country.

Table 23.5 Summary of observed street dirt mean chemical quality (mg constituent/kg solids).

\begin{tabular}{|c|c|c|c|}
\hline Constituent & Residential & Commercial & Industrial \\
\hline \multirow[t]{5}{*}{$\mathrm{P}$} & $620(4)$ & & \\
\hline & $540(6)$ & & $670 \quad(4)$ \\
\hline & $1100(5)$ & $400(6)$ & \\
\hline & $710(1)$ & $1500(5)$ & \\
\hline & 810 & 910 (1) & \\
\hline \multirow[t]{5}{*}{ TKN } & $1030(4)$ & & \\
\hline & $3000(6)$ & & 560 \\
\hline & $290(5)$ & $1100(6)$ & \\
\hline & 2630 & 340 & \\
\hline & 3000 (2) & $4300(2)$ & \\
\hline \multirow[t]{6}{*}{ COD } & $100,000(4)$ & & \\
\hline & $150,000(6)$ & & $65,000(4)$ \\
\hline & $180,000 \quad(5)$ & $110,000(6)$ & \\
\hline & 280,000 (1) & $250,000 \quad(5)$ & \\
\hline & $180,000 \quad(3)$ & $340,000(1)$ & \\
\hline & 170,000 (2) & $210,000 \quad(2)$ & \\
\hline \multirow[t]{3}{*}{$\mathrm{Cu}$} & $162(4)$ & & \\
\hline & $110(6)$ & $130(6)$ & 360 \\
\hline & $420(2)$ & $220(2)$ & \\
\hline \multirow[t]{6}{*}{$\mathrm{Pb}$} & $1010(4)$ & & \\
\hline & $1800(6)$ & & $900 \quad$ (4) \\
\hline & $530(5)$ & $3500(6)$ & \\
\hline & $1200(1)$ & $2600(5)$ & \\
\hline & 1650 (3) & 2400 & \\
\hline & 3500 (2) & 7500 (2) & \\
\hline \multirow{4}{*}{$\mathrm{Zn}$} & 460 (4) & & \\
\hline & 260 & & 500 \\
\hline & $325(3)$ & $750(5)$ & \\
\hline & $680(2)$ & 1200 (2) & \\
\hline \multirow[t]{2}{*}{$\mathrm{Cd}$} & $<3(5)$ & $5(5)$ & \\
\hline & $4(2)$ & $5(2)$ & \\
\hline \multirow[t]{3}{*}{$\mathrm{Cr}$} & $42(4)$ & & \\
\hline & $31(5)$ & $65(5)$ & $70 \quad(4)$ \\
\hline & $170(2)$ & $180(2)$ & \\
\hline \multicolumn{4}{|c|}{$\begin{array}{l}\text { References; location; particle size described in Table 23.5: } \\
\text { (1) Bannerman, et al. } 1983 \text { (Milwaukee, WI) }<31 \mu \mathrm{m} \\
\text { (2) Pitt } 1979 \text { (San Jose, CA) }<45 \mu \mathrm{m} \\
\text { (3) Pitt } 1985 \text { (Bellevue, WA) }<63 \mu \mathrm{m} \\
\text { (4) Pitt and McLean } 1986 \text { (Toronto, Ontario) }<125 \mu \mathrm{m} \\
\text { (5) Pitt and Sutherland } 1982 \text { (Reno/Sparks, NV) }<63 \mu \mathrm{m} \\
\text { (6) Terstriep, et al. } 1982 \text { (Champaign/Urbana, IL) }<63 \mu \mathrm{m}\end{array}$} \\
\hline
\end{tabular}


Increasing concentrations of heavy metals with decreasing particle sizes was also evident, for those studies that included particle size information. However, phosphorus concentrations typically increased with increasing particle sizes. Only the quality of the smallest particle sizes are shown on these tables because they best represent the particles that are washed off during rains.

\subsubsection{Sheetflow Quality}

The data presented in this section are divided into four sections: data from early sheetflow monitoring projects in the early 1980s, data from the Birmingham, AL, source area project conducted for the EPA in the mid 1990s, data from a series of related projects conducted in Wisconsin by the WI DNR and the USGS used to calibrate the Source Loading and Management Model (SLAMM) from the early and mid 1990s, and a bibliography of more recent source area runoff studies conducted throughout the world during the late 1990s and early 2000s.

\subsubsection{Early Sheetflow Monitoring Results}

Sheetflow data, collected during actual rain events, are probably more representative of runoff conditions than the previously presented dry particulate quality data because they are not further modified by washoff mechanisms. Pitt (1987) conducted numerous washoff tests to supplement early tests conducted by Sartor and Boyd (1972), and accumulation and washoff data are presented in a related chapter of this book. These data, in conjunction with source area flow quantity information, can be used to predict outfall conditions and the magnitude of the relative sources of critical pollutants (as done in the Source Loading and Management Model, SLAMM, http://rpitt.eng.ua.edu/SLAMMDETPOND/MainSLAMMDETPOND.html and Pitt and Voorhees 1995). Tables 23.7 through 23.10 summarize warm weather sheetflow observations, separated by source area type and land use, from many locations. Table 23.7 (sheetflow quality summary for other source areas) has been placed in the appendix at the end of this monograph. 
Table 23.6 Summary of observed particulate quality for other source areas (means for $<125 \mu \mathrm{m}$ particles) (mg constituent/kg solids).

\begin{tabular}{lrrrrrrr}
\hline & $\mathrm{P}$ & $\mathrm{TKN}$ & $\mathrm{COD}$ & $\mathrm{Cu}$ & $\mathrm{Pb}$ & $\mathrm{Zn}$ & $\mathrm{Cr}$ \\
\hline Residential/Commercial & & & & & & & \\
Land Uses & & & & & & & \\
$\quad$ Roofs & & & & & & & \\
$\quad$ Paved parking & 1500 & 5700 & 240,000 & 130 & 980 & 1900 & 77 \\
Unpaved driveways & 600 & 790 & 78,000 & 145 & 630 & 420 & 47 \\
$\quad$ Paved driveways & 400 & 850 & 50,000 & 45 & 160 & 170 & 20 \\
$\quad$ Dirt footpath & 550 & 2750 & 250,000 & 170 & 900 & 800 & 70 \\
$\quad$ Paved sidewalk & 360 & 760 & 25,000 & 15 & 38 & 50 & 25 \\
$\quad$ Garden soil & 1100 & 3620 & 146,000 & 44 & 1200 & 430 & 32 \\
$\quad$ Road shoulder & 1300 & 1950 & 70,000 & 30 & 50 & 120 & 35 \\
& 870 & 720 & 35,000 & 35 & 230 & 120 & 25 \\
\hline Industrial Land Uses & & & & & & & \\
Paved parking & 770 & 1060 & 130,000 & 1110 & 650 & 930 & 98 \\
Unpaved & & & & & & & \\
parking/storage & 620 & 700 & 110,000 & 1120 & 2050 & 1120 & 62 \\
Paved footpath & 890 & 1900 & 120,000 & 280 & 460 & 1300 & 63 \\
Bare ground & 700 & 1700 & 70,000 & 91 & 135 & 270 & 38 \\
\hline
\end{tabular}

Source: Pitt and McLean 1986 (Toronto, Ontario)

The major source area categories examined are listed below:

1. roofs

2. paved parking areas

3. paved storage areas

4. unpaved parking and storage areas

5. paved driveways

6. unpaved driveways

7. dirt walks

8. paved sidewalks

9. $\quad$ streets

10. landscaped areas

11. undeveloped areas

12. freeway paved lanes and shoulders 
Table 23.8. Sheetflow quality summary for undeveloped landscaped and freeway pavement areas (mean concentrations and source of data).

\begin{tabular}{|c|c|c|c|}
\hline Pollutants & Landscaped Areas & Undeveloped Areas & $\begin{array}{l}\text { Freeway Paved Lane and } \\
\text { Shoulder Areas }\end{array}$ \\
\hline $\begin{array}{l}\text { Total Solids, mg/L } \\
\text { Suspended Solids, } \\
\mathrm{mg} / \mathrm{L}\end{array}$ & $\begin{array}{l}388(4) \\
100(4)\end{array}$ & $\begin{array}{l}588 \text { (4) } \\
400(1) \\
390(4)\end{array}$ & $\begin{array}{l}340(5) \\
180(5)\end{array}$ \\
\hline $\begin{array}{l}\text { Dissolved Solids, } \\
\mathrm{mg} / \mathrm{L}\end{array}$ & 288 (4) & 193 (4) & $160(5)$ \\
\hline $\mathrm{BOD}_{5}, \mathrm{mg} / \mathrm{L}$ & $\begin{array}{l}3(3) \\
70(3)\end{array}$ & $-\ldots$ & $10(5)$ \\
\hline $\mathrm{COD}, \mathrm{mg} / \mathrm{L}$ & $26(4)$ & $\begin{array}{l}72(1) \\
54(4)\end{array}$ & $130(5)$ \\
\hline $\begin{array}{l}\text { Total Phosphorus, } \\
\text { mg/L }\end{array}$ & $\begin{array}{l}0.42(3) \\
0.56(4)\end{array}$ & $\begin{array}{l}0.40(1) \\
0.68 \text { (4) }\end{array}$ &.-- \\
\hline $\begin{array}{l}\text { Total Phosphate, } \\
\mathrm{mg} / \mathrm{L}\end{array}$ & $\begin{array}{l}0.32(3) \\
0.14(4)\end{array}$ & $\begin{array}{l}0.10 \\
0.26\end{array}$ & $0.38(5)$ \\
\hline $\mathrm{TKN}, \mathrm{mg} / \mathrm{L}$ & $\begin{array}{l}1.32(3) \\
(4)\end{array}$ & $\begin{array}{l}2.9(1) \\
1.8(4)\end{array}$ & $2.5(5)$ \\
\hline Ammonia, mg/L & $\begin{array}{l}(3) \\
(4)\end{array}$ & $\begin{array}{r}0.1 \text { (1) } \\
<0.1 \text { (4) }\end{array}$ & $-\cdots$ \\
\hline Phenols, $\mu \mathrm{g} / \mathrm{L}$ & $\begin{array}{l}(4) \\
(4)\end{array}$ & $11(4)$ & 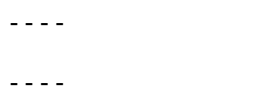 \\
\hline Aluminum, $\mu \mathrm{g} / \mathrm{L}$ & $<3$ (4) & $<4$ & $60(5)$ \\
\hline Cadmium, $\mu \mathrm{g} / \mathrm{L}$ & $10(3)$ & $<60$ (4) & $70(5)$ \\
\hline $\begin{array}{l}\text { Chromium, } \mu \mathrm{g} / \mathrm{L} \\
\text { Copper, } \mu \mathrm{g} / \mathrm{L}\end{array}$ & $<20$ & $\begin{array}{r}40(1) \\
31(3) \\
<20(4)\end{array}$ & $120(5)$ \\
\hline Lead, $\mu \mathrm{g} / \mathrm{L}$ & $\begin{array}{l}30(2) \\
35(3) \\
<30(4)\end{array}$ & $\begin{array}{r}100(1) \\
30(2) \\
<40(4)\end{array}$ & $2000(5)$ \\
\hline Zinc, $\mu \mathrm{g} / \mathrm{L}$ & $10(3)$ & $\begin{array}{l}100(1) \\
100(4)\end{array}$ & $460(5)$ \\
\hline
\end{tabular}

References:

(1) Denver Regional Council of Governments 1983 (NURP)

(2) Pitt 1983 (Ottawa)

(3) Pitt and Bozeman 1982 (San Jose)

(4) Pitt and McLean 1986 (Toronto)

(5) Shelly and Gaboury 1986 (Milwaukee) 
Table 23.9, source area bacteria sheetflow quality summary, and Table 23.10, Source area filterable pollutant concentration summary, have been placed in the appendix at the back of his book.

Toronto warm weather sheetflow water quality data were plotted against the rain volume that had occurred before the samples were collected to identify any possible trends of concentrations with rain volume (Pitt and McLean 1986). The street runoff data obtained during the special washoff tests were also compared with the street sheetflow data obtained during the actual rain events (Pitt 1987). These data observations showed definite trends of solids concentrations verses rain volume for most of the source area categories. Sheetflows from all pervious areas combined had the highest total solids concentrations from any source category, for all rain events. Other paved areas (besides streets) had total solids concentrations similar to runoff from smooth industrial streets. The concentrations of total solids in roof runoff were almost constant for all rain events, being slightly lower for small rains than for large rains. No other pollutant, besides SS, had observed trends of concentrations with rain depths for the samples collected in Toronto. Lead and zinc concentrations were highest in sheetflows from paved parking areas and streets, with some high zinc concentrations also found in roof drainage samples. High bacteria populations were found in sidewalk, road, and some bare ground sheetflow samples (collected from locations where dogs would most likely be "walked").

Some of the Toronto sheetflow contributions were not sufficient to explain the concentrations of some constituents observed in stormwater at the outfall. High concentrations of dissolved chromium, dissolved copper, and dissolved zinc in a Toronto industrial outfall during both wet and dry weather could not be explained by wet weather sheetflow observations (Pitt and McLean 1986). As an example, very few detectable chromium observations were obtained in any of the more than 100 surface sheetflow samples analyzed. Similarly, most of the fecal coliform values observed in sheetflows were significantly lower than those observed at the outfall. It is expected that some industrial wastes, possibly originating from metal plating operations, were the cause of the high concentrations of dissolved metals at the outfall and that some sanitary sewage was entering the storm drainage system. Table 23.10 summarizes the little filterable pollutant concentration data available for different source areas from these earlier tests. Most of the available data are for residential roofs and commercial parking lots. 


\subsection{Conclusions}

Source area sheetflow data can be used to identify critical source areas that should receive special attention when designing a stormwater management program. This information is also useful when calibrating stormwater quality models, especially when it has simultaneous outfall data. The information presented in this chapter are summaries from a large number of separate monitoring projects conducted in many locations of the US, and represent a wide range of land uses and source area types. The total number of samples is also relatively large. However, these data are presented as simple averages, along with some variations, for the source areas and no significant statistical analyses have been conducted. This may be suitable for model calibration, especially in areas where the data has been collected, but a complete database containing all data and comprehensive analyses would add greatly to our understanding of stormwater problems. The authors are in the process of collecting these data together for such a database.

The past studies also have tremendous guidance information concerning sample collection and analysis. These activities require special attention when attempting to monitor a large number of locations simultaneously. Burton and Pitt (2002) have recently summarized these sampling (and experimental design) approaches suitable for source area monitoring, along with many other elements of a comprehensive monitoring program.

Many studies have concluded that automobiles contribute many important heavy metals to street surface particulates and to urban runoff and receiving waters. Tire wear is an important zinc source. The role of atmospheric deposition is less clear and is frequently confused. Urban atmospheric deposition information must be interpreted carefully, because of the ability of many polluted dust and dirt particles to be resuspended and then redeposited within the urban area. In many cases, the atmospheric deposition measurements include material that was previously residing and measured in other urban runoff pollutant source areas. Also, only small amounts of the atmospheric deposition material would directly contribute to runoff. Rain is subjected to infiltration and the dry fall particulates are likely mostly incorporated with surface soils and only small fractions are then eroded during rains. Therefore, mass balances and determinations of urban runoff deposition and accumulation from different source areas can be highly misleading, unless transfer of material between source areas and the effective yield of this material to the receiving water is considered. Depending on the 
land use, relatively little of the dustfall in urban areas likely contributes to stormwater discharges.

Data observations of sheetflow suspended solids showed definite trends of decreasing concentrations verses increasing rain volumes for most of the source area categories. However, sheetflows from pervious areas had the highest total solids concentrations observed for any source category, and for all rain events.

\section{References}

Bannerman, R., K. M. Baun, P. E. Bohn, and D. A. Graczyk. Evaluation of Urban Nonpoint Source Pollution Management in Milwaukee County, Wisconsin. PB 84114164. U.S. Environmental Protection Agency. Chicago, IL. 1983

Barkdoll, M. P., D. E. Overton, and R. P. Beton. Some effects of dustfall on urban stormwater quality. Water Pollution Control Federation. 49(9):1976-84. 1977

Betson, R. P. Precipitation and streamflow quality relationships in an urban area. Water Resources Research. 14(6):1165-1169. 1978

Burton, G.A. Jr., and R. Pitt. Stormwater Effects Handbook: A Tool Box for Watershed Managers, Scientists, and Engineers. CRC Press, Inc., Boca Raton, FL. 2002. 911 pages.

Cowherd, C. J., C. M. Maxwell, and D. W. Nelson. Quantification of Dust Entrainment from Paved Roadways. EPA-450 3-77-027. U.S. Environmental Protection Agency. Research Triangle Park, NC. July. 1977

Denver Regional Council of Governments. Urban Runoff Quality in the Denver (Colorado) Region. Prepared for the U.S. EPA. Washington, DC. PB85-101640. September. 1983

EPA. Results of the Nationwide Urban Runoff Program. Water Planning Division. PB 84185552. Washington, D.C. December. 1983

Gupta, M., D. Mason, M. Clark, T. Meinholz, C. Hansen, and A Geinopolos. Screening Flotation Treatment of Combined Sewer Overflows Volume I - Bench Scale and Pilot Plant Investigations. EPA-600/2-77-069a. U.S. Environmental Protection Agency. Cincinnati, OH. August. 1977

Kobriger, N.P., T.L. Meinholiz, M.K. Gupta, and R.W. Agnew. Constituents of Highway Runoff. Vol. 3. Predictive Procedure for Determining Pollution Characteristics in Highway Runoff. FHWA/RD-81/044. Federal Highway Administration. Washington, D.C. February. 1981

Koeppe, D. E. comp. Vol. IV: Soil-water-air-plant studies. In: Environmental Contamination by Lead and Other Heavy Metals. G. L. Rolfe and K. A. Peinbold, eds. Institute for Environmental Studies. Univ. of Illinois. Urbana-Champaign, IL. July. 1977

Malmquist, Per-Arne. Atmospheric Fallout and Street Cleaning - Effects on Urban Stream Water and Snow. Prog. Wat Tech., 10(5/6): 495-505. Pergamon Press. Great Britain. September. 1978 
Manning, M.J., R.H. Sullivan, and T.M. Kipp. Nationwide Evaluation of Combined Sewer Overflows and Urban Stormwater Discharges. Vol. III: Characterization of Discharges. U.S. Environmental Protection Agency. Cincinnati, OH. October. 1976

Murphy, W. Roadway Particulate Losses. American Public Works Assoc. Unpublished. 1975

PEDCo-Environmental, Inc. Control of Re-entrained Dust from Paved Streets. EPA-907/977-007. U.S. Environmental Protection Agency. Kansas City, MO. 1977

Pitt, R. Demonstration of Nonpoint Pollution Abatement Through Improved Street Cleaning Practices. EPA-600/2-79-161. U.S. Environmental Protection Agency. Cincinnati, OH. August. 1979

Pitt R. and M. Bozeman. Sources of Urban Runoff Pollution and Its Effects on an Urban Creek. EPA 600/S2-82-090. U.S. Environmental Protection Agency. Cincinnati, OH. 1982

Pitt, R. and R. Sutherland. Washoe County Urban Stormwater Management Program. Volume 2, Street Particulate Data Collection and Analyses. Washoe Council of Governments. Reno, NV. August. 1982

Pitt, R. Urban Bacteria Sources and Control in the Lower Rideau River Watershed. Ottawa, Ontario. Ontario Ministry of the Environment. ISBN 0-7743-8487-5. 165 pgs. 1983

Pitt, R. Characterizing and Controlling Urban Runoff through Street and Sewerage Cleaning. U.S. Environmental Protection Agency. Storm and Combined Sewer Program. Risk Reduction Engineering Laboratory. EPA/600/S2-85/038. PB 85186500. Cincinnati, OH. June. 1985

Pitt, R. and J. McLean. Toronto Area Watershed Management Strategy Study. Humber River Pilot Watershed Project. Ontario Ministry of the Environment. Toronto, Ontario. 1986

Pitt, R. Small Storm Urban Flow and Particulate Washoff Contributions to Outfall Discharges. Ph.D. dissertation submitted to the Department of Civil and Environmental Engineering. University of Wisconsin - Madison. 1987

Pitt, R. and J. Voorhees. "Source loading and management model (SLAMM)." Seminar Publication: National Conference on Urban Runoff Management: Enhancing Urban Watershed Management at the Local, County, and State Levels. March 30 - April 2, 1993. Center for Environmental Research Information, U.S. Environmental Protection Agency. EPA/625/R-95/003. Cincinnati. Ohio. pp. 225-243. April 1995.

Rolfe, G.L. and K.A. Reinhold. Vol. I.- Introduction and Summary. Environmental Contamination by Lead and Other Heavy Metals. Institute for Environmental Studies. University of Illinois. Champaign-Urbana, IL. July. 1977

Rubin, A. J., ed. Aqueous-Environmental Chemistry of Metals. Ann Arbor Science Publishers. Ann Arbor, MI. 1976

Sartor J. and G. Boyd. Water Pollution Aspects of Street Surface Contaminants. EPA-R272-081, U.S. Environmental Protection Agency. November. 1972

Shaheen, D.G. Contributions of Urban Roadway Usage to Water Pollution. 600/2-75-004. U.S. Environmental Protection Agency. Washington, D.C. April. 1975

Shelley, P.E. and D.R. Gaboury. Estimation of pollution from highway runoff - initial results. Conference on Urban Runoff Quality - Impact and Quality Enhancement Technology. Henniker, NH. Edited by B. Urbonas and L.A. Roesner. Proceedings published by the American Society of Civil Engineering. New York, NY. June. 1986 
Solomon, R.L., and D.F.S. Natusch. Vol:1ll: Distribution and characterization of urban dists. In: Environmental Contamination by Lead and Other Heavy Metals. G. L. Rolfe and K. G. Reinbold, eds. Institute for Environmental Studies. Univ. of Illinois. UrbanaChampaign, IL. July. 1977

Spring, R. J., R. B. Howell, and E. Shirley. Dustfall Analysis for the Pavement Storm Runoff Study (I-405 Los Angeles). Office of Transportation Laboratory. California Dept. of Transportation. Sacramento, CA. April. 1978

Terstriep, M.L., G.M. Bender, and D.C. Noel. Final Report - NURP Project, Champaign, Illinois: Evaluation of the Effectiveness of Municipal Street Sweeping in the Control of Urban Storm Runoff Pollution. State Water Survey Division. Illinois Dept. of Energy and Natural Resources. Champaign-Urbana, IL. December. 1982

Wilber, W. G., and J.V. Hunter. The Influence of Urbanization on the Transport of Heavy Metals in New Jersey Streams. Water Resources Research Institute. Rutgers University. New Brunswick, NJ. 1980. 
